\title{
Design and Implementation of Support System for Student Laboratory Using Database and Web Server
}

\author{
Masashi Ohchi Member (Saga University, masashi@ace.ec.saga-u.ac.jp) \\ Norio Aoki Student Member (Saga University, aoki@ace.ec.saga-u.ac.jp) \\ Tatsuya Furukawa Member (Saga University, tach@ace.ec.saga-u.ac.jp) \\ Toshihiro Kawahara Non-member (YASKAWA INFORMATION SYSTEMS Corporation)
}

Keywords: student laboratory, database, Web Server

The student laboratory is an essential subject in the engineering departments of universities. However it is hard for teachers and students to implement. In our Department of Electrical and Electronic Engineering in Saga University, the support environment is insufficient to conduct the student laboratory. In order to overcome the problem, it is considered to implement the support system for the student laboratory using database and Web server.

In the paper, we will describe the design and implementation of student laboratory support system based on the Web technology using the Database.

Figure 1 shows the system configuration of student laboratory support system based on the Web technology using PostgreSQL. The system consists of the attendance and score management system, the experimental instrument management system and the preparation support system.

In the attendance and score management system, the attendance and score data can be easily inputted, changed and confirmed using the Web browser. The teacher is able to see the average, variance and standard deviation of the scores.

Figure 2 shows the flowchart for the reservation of student laboratory instruments. In the system, it is able to reserve the student laboratory instruments using the Web browser.

Figure 3 show the configuration of the student laboratory instrument lending system. The system uses the bar-code reader to verify the instrument and student.

Figure 4 shows the snapshot of the preparation support system for the student laboratory. The student must select an answer from several choices to the questions. The scores and date of the preparation are preserved using the database management system.

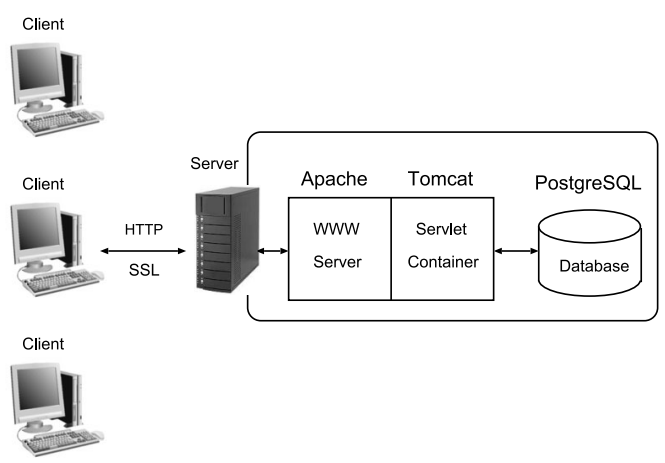

Fig. 1. System configuration
It is considered that the implemented system is the extremely useful support system of the student laboratory for teachers and students.

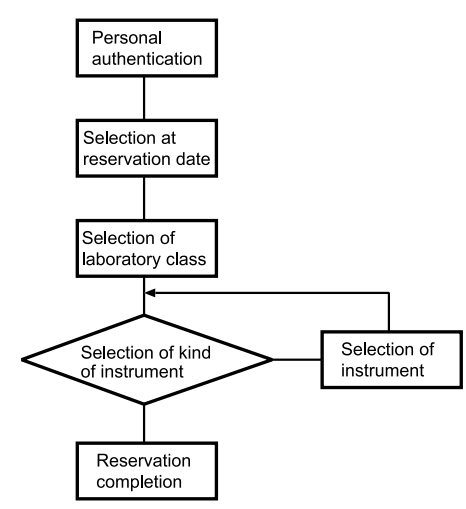

Fig. 2. Flowchart for reservation of student laboratory instruments

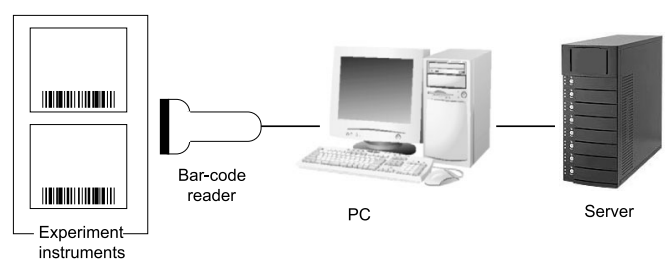

Fig. 3. System configuration of student laboratory instrument lending

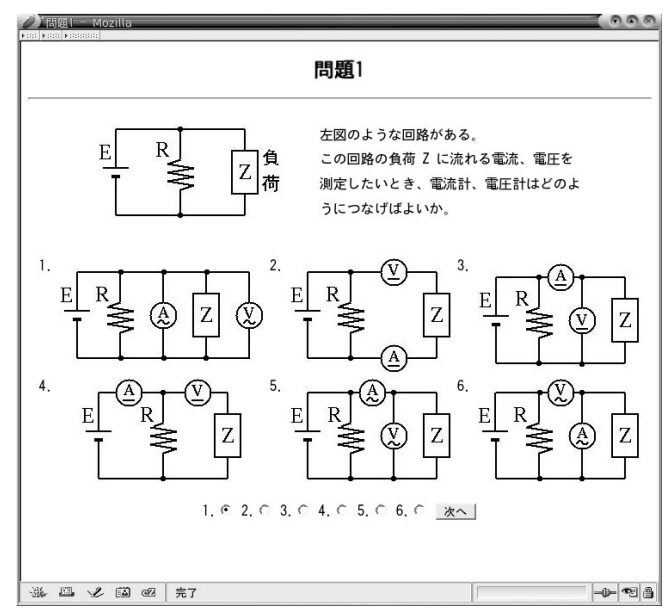

Fig. 4. Question window 


\title{
データベースとWebサーバを用いた学生実験支援システムの 設計と実装
}

\author{
正 員 相知 政司* 学生員 青木 規至* \\ 正 員 古川 達也* 非会員 川原 俊宏**
}

\author{
Design and Implementation of Support System for Student Laboratory \\ Using Database and Web Server \\ Masashi Ohchi*, Member, Noriyuki Aoki*, Student Member, \\ Tatsuya Furukawa*, Member, Toshihiro Kawahara**, Non-member
}

The student laboratory is an essential subject in the engineering departments of universities. However it is hard for both teachers and students to implement that. In our Department of Electrical and Electronic Engineering in Saga University, the support environment is said to be insufficient to conduct the student laboratory. In order to overcome the problem, it is effective to implement the support system for the student laboratory using database and Web server. In the paper, we will describe the design and the implementation of student laboratory support system based on the Web technology using the Database.

キーワード : 学生実験, データベース, Web サーバ

Keywords: student laboratory, database, Web server

\section{1. はじめに}

大学の工学系学科において, 学生実験は非常に重要な科 目である。しかし，同時に，受講者にとっても教員にとっ ても非常に負荷の大きな科目でもあるため, 多様な学生実 験システムの取り組みが現在も模索されている(1)。

佐賀大学理工学部電気電子工学科では, 平成 15 年度か ら新カリキュラムを実施し，これまで以上に学生実験を重 要視している。しかし, 当学科の学生実験は, 学生実験並 びに関連する教務事務を支援する環境が未だ十分であると は言えない。一方，多くの大学においても，学生実験は同 様な状況ではないかと考えられる。

当学科の学生実験は, 複数の実験室で行われているため, 受講者の出席確認について集計が煩雑である。また, 受講 者の成績は，実験の各テーマ毎にそれぞれの担当の教員が 成績評価を行っている。したがって，最終的な成績を決め

\footnotetext{
* 佐賀大学理工学部電気電子工学科

于 840-8502 佐賀市本庄町 1 番地

Department of Electrical and Electronic Engineering, Faculty of Science and Engineering, Saga University

1, Honjo-machi, Saga 840-8502

** 安川情報システム (株)

₹ 806-0037 北九州市八幡西区東王子町 5 番 15 号

YASKAWA INFORMATION SYSTEMS Corporation

5-15, Higashioji, Yahatanishi, Kitakyushu, 806-0037
}

る際に, 各テーマ毎の成績の平均化を行わなければならな い。成績を集計する際に, 教員は商用ソフトウェアのスプ レッドシートファイルをメールで交換しているが，この方 法では成績データを一元管理する点で問題が残る。

次に，従来，受講者は決められた時間にしか学生実験を行 うことができなかったが, JABEE (Japan Accreditation Board for Engineering Education) ${ }^{(2)}$ で求められるデザ イン能力の養成のため, 教職員の立会いがなくても, 安全 上問題ない範囲で受講者が他の授業のない時間を利用して 自由に実験が行える環境を整える必要が出てきた。また，実 験器具について, いつ, 誰がどの実験器具を使ったという データの管理がなされていないため, 実験器具の故障の発 見が遅れたり, 実験器具の所在が不明になるなどの問題が あり，授業に支障をきたすことがある。そこで，実験器具 について使用履歴を含めた管理を行う必要がある。

さらに，学生実験を行う際には，予習を十分に行って実験 に臨まなければならない。しかし，当学科において予習が 不十分であったり, 予習が行われていないという状況が少 なからずある。予習が不十分であると, 受講者自らが積極 的に実験に取り組むことができなかったり，同じグループ の他人に実験を任せっきりになってしまう。これでは, 当学 科の学生実験の目的である,「電気電子工学における法則を 直接に体験しそれらを深く理解する」ことを達成できない。 筆者らは，従前から Web ベースの仮想実験室 ${ }^{(3)}$ (4) や大 
学教務事務支援システム(5) を提案しており，同様のネット ワーク技術を学生実験に適用できないかと考えた。

このような背景の中, 本研究ではこれらの問題について データベースと Web サーバを用いて学生実験における環 境の支援を目的としたシステムの設計・実装を行った。本 システムによって教員側，受講者側の両方にとってより充 実した実験並びに教務支援環境となると考えられる。

本研究では Web サーバには Apache ${ }^{(6)}$ を, データベー ス・マネージメント・システムには PostgreSQL (7) を用い て, 学生実験支援システムとして出席・成績管理システム, 実験器具管理システム，予習支援システムの開発を行った ので，その詳細を報告する。

\section{2. 学生実験支援システム}

図 1 に，本研究で設計・実装した学生実験支援システム のシステム構成を示す。本システムでは, Web サーバとし て Apache を用い, Web ページの作成を HTML (Hyper Text Markup Language) にて行った。また，サーブレッ トコンテナとして Tomcat ${ }^{(8)}$ を使用し，データの管理を行 うデータベースに PostgreSQL を用いている。Webページ の動的な部分の作成およびデータベースとの連携を行う際 には，JSP (Java Server Pages) を使用している。

JSP は，以下のような特徵を有する。

・Javaのマルチプラットフォーム対応の性質を受け継い でいるため, Linux 環境でも Windows 環境でも使用 することができる。

・実行エンジンである Tomcat によって一度コンパイル され実行されれば，それ以降はメモリ上に常駐された 状態で実行されるため，新しいプロセスを起動するこ となく，オーバヘッドとリソースの消費が少なく効率 的である。

・サーバ側でプログラムを実行してページを生成するた め，クライアント側の実行環境に依存しない。

また，本システムでは出席や成績の管理を行っており，情

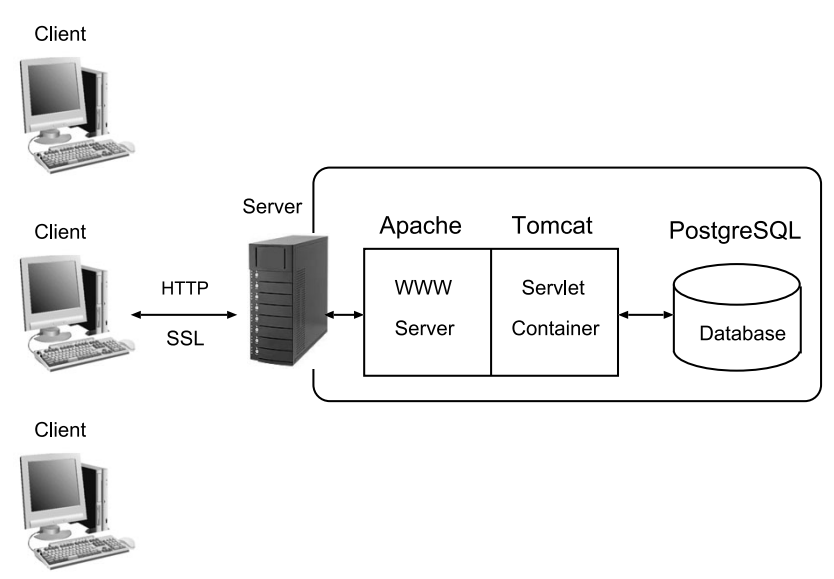

図 1 システム構成

Fig. 1. System configuration.
報の機密性を確保するため，SSL (9) を用いた暗号化通信を 行っている。

利用者が本システムの Web ページにアクセスすると，以 下に挙げる三つのシステムを利用することができる。

・出席・成績管理システム

- 実験器具管理システム

・予習支援システム

出席・成績管理システムでは, 出席データの管理と成績 データの管理を行うことが可能となっている。出席データ の管理では, 出席デー夕の入力, 変更, また入力されたデー 夕の一覧表示を行うことができる。成績デー夕の管理では, 出席デー夕の管理と同様に, 成績デー夕の入力, 変更, ま た入力されたデータの一覧表示を行うことができる。成績 デー夕の一覧表示では, 入力された成績データのほかに, 平 均点，分散，標準偏差も同時に閲覧することができる。

実験器具管理システムでは, 実験器具の予約と実験器具 の貸出処理を行うことが可能である。実験器具の予約では, 受講者が希望する日時に希望する実験器具の予約を行うこ とが可能となっている。実験器具の貸出では, バーコード リーダを利用して実験器具の管理を行う。

予習支援システムは, 受講者が問題形式で学生実験の予 習を行うことが可能なシステムである。また，予習を行っ た履歴や参考文献の提示も行う。

$\langle 2 \cdot 1\rangle$ 出席・成績管理システム出席・成績管理シス テムにおいて，まず，出席管理システムについて説明する。 本システムにおいて, 出席入力ページを選択し, 年度と第 何週目かを選択すると, 図 2 の出席入力ページが表示され る。本画面において出欠入力を行う際には, 選択された週 の列が出席か欠席か選択するようになっているため，各受

\begin{tabular}{|c|c|c|c|c|c|c|c|c|c|}
\hline \multicolumn{9}{|c|}{ 2004年度前半 } & \\
\hline 学籍番号 & 名前 & \multirow{2}{*}{\begin{tabular}{|c|} 
第1週 \\
0 \\
\end{tabular}} & \multirow{2}{*}{\begin{tabular}{|c|} 
第2週 \\
0
\end{tabular}} & 第3週 & \multirow{2}{*}{\begin{tabular}{|c|} 
第4週 \\
-
\end{tabular}} & \multirow{2}{*}{\begin{tabular}{|c|} 
第5週 \\
- \\
\end{tabular}} & \multirow{2}{*}{$\begin{array}{c}\text { 第6週 } \\
-\end{array}$} & \multirow{2}{*}{\begin{tabular}{|c|} 
第7週 \\
- \\
\end{tabular}} & \\
\hline 04236077 & $\pm=$ & & & 出席 ‘ 欠席 & & & & & \\
\hline 04236085 & 1nit & $x$ & $x$ & 出席 $\ulcorner$ 欠席 $\odot$ & - & - & - & - & \\
\hline 04236093 & 11 & 0 & 0 & 出席 〔 欠席 $r$ & - & - & - & - & \\
\hline 04236006 & 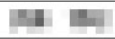 & 0 & 0 & 出席 • 欠席 $r$ & - & - & - & - & \\
\hline 04236014 & $n=1$ & 0 & 0 & 出席 ‘ 欠席 & - & - & - & - & \\
\hline 04236022 & ni & 0 & 0 & 出席 • 久席 & - & - & - & - & \\
\hline 04236030 & 1 & 0 & 0 & 出席‧ 欠席 & - & - & - & - & \\
\hline 04236038 & 래 & 0 & 0 & 出席 〔 欠席 & - & - & - & - & \\
\hline 04236046 & Hin & 0 & 0 & 出席 ‘ 欠席 & - & - & - & - & \\
\hline 04236054 & 111 & 0 & 0 & 出席 欠席 & - & - & - & - & \\
\hline 04236062 & nat aㅏ & 0 & 0 & 出席 ‘ 欠席 $r$ & - & - & - & - & \\
\hline 04236070 & 1. & 0 & $\mathrm{O}$ & 出席 ‘ 欠席 & - & - & - & - & \\
\hline 04236078 & 메 & 0 & 0 & 出席 ‘ 欠席 $r$ & - & - & - & - & \\
\hline 04236086 & 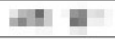 & O & 0 & 出席 ‘ 欠席 「 & - & - & - & - & \\
\hline 04236094 & - 드 & 0 & $x$ & 出席‧ 欠席 「 & - & - & - & - & \\
\hline 04236007 & - & 0 & 0 & 出席 ‘ 欠席 & - & - & - & - & 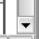 \\
\hline 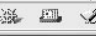 & 国 $\mathrm{Cl}=$ & 3 & & & & & & $-0=\pi$ & 19 \\
\hline
\end{tabular}

図 2 出席入力画面

Fig. 2. Attendance input window. 


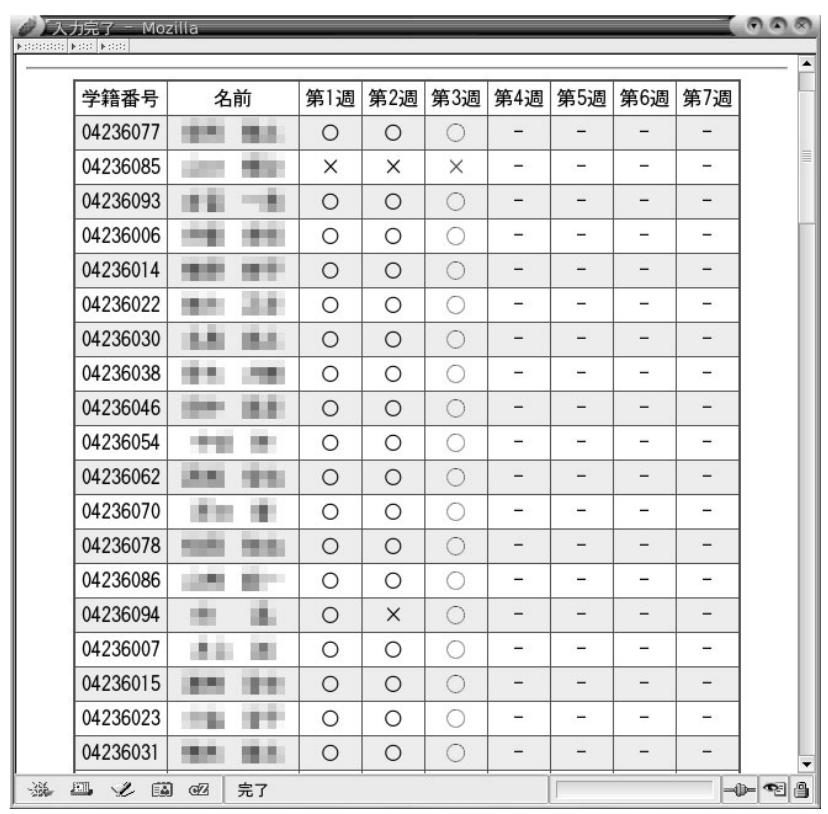

図 3 出席一覧表

Fig. 3. Attendance table.

講者の出席状況に応じて選択する。受講者の出席状況の選 択を終了して登録ボタンを選択すると，データベースに出 席デー夕が登録され，出席入力は終了となる。

また，出席デー夕は変更を行うことも可能である。出席 デー夕の変更も最初に出席入力を行う際と同様に年度と第 何週目かを選択し，出席入力ページを表示する。ここで，選 択された週が出席か欠席かを選択するが，出席デー夕が既 にデータベースに登録されている場合，出席データを元に 出席, 欠席が選択されているため, 変更箇所だけを選択し 直す。選択終了後，登録ボタンを選択すると，データベース の出席デー夕が更新され，出席デー夕の変更は終了となる。

次に本システムにおいて出席状況の確認ページを選択す ると，図 3 のような出席一覧表が表示される。出席一覧表 では，全員の出席状況を閲覽することができる。出席一覧 表において○は出席を表し，×は久席を表している。

次に出席・成績管理システムに扔ける，成績管理システム について説明する。本システムに扣いて，成績入力ページ を選択し，年度と前半の成績の入力，または後半の成績の 入力のどちらかを選択すると, 図 4 のページが表示される。 ここで例として取り挙げる学生実験の成績は, 前半の実験 と後半の実験の二テーマの成績を評価し, 前半の成績と後 半の成績の平均值が学生実験の成績となっている。そのた め, 前半の成績と後半の成績の入力を行う必要がある。成 績は各受講者毎に成績デー夕を入力し，すべてのデー夕を 入力後，登録ボタンを選択するとデータベースに成績デー 夕が登録され，成績データの入力は終了する。

また，成績デー夕は変更を行うことも可能である。成績 データの変更も, 年度と前半の成績の入力, または後半の 成績の入力のどちらかを選択し，成績データの変更を行う。 ここでも，あらかじめ成績データが登録されていれば，そ

\section{4年度}

\begin{tabular}{|c|c|c|c|c|}
\hline 学籍番号 & 名前 & 前半 & 後半 & 合計 \\
\hline 04236001 & ㅁ.1 & 40 & 35 & 75 \\
\hline 04236009 & $+1+1$ & 40 & 35 & 75 \\
\hline 04236017 & -11 & 40 & 35 & 75 \\
\hline 04236025 & H11 & 40 & 35 & 75 \\
\hline 04236033 & In 1 & 40 & 35 & 75 \\
\hline 04236041 & 1111 & 40 & 35 & 75 \\
\hline 04236049 & $11=1$ & 40 & 35 & 75 \\
\hline 04236057 & 11 & 40 & 35 & 75 \\
\hline 04236065 & 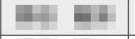 & 40 & 35 & 75 \\
\hline 04236073 & 41 & 40 & 35 & 75 \\
\hline 04236081 & 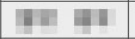 & 40 & 35 & 75 \\
\hline 04236089 & 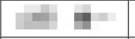 & 40 & 35 & 75 \\
\hline 04236002 & 1010 & 40 & 40 & 80 \\
\hline 04236010 & $4=1$ & 40 & 40 & 80 \\
\hline 04236018 & 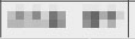 & 40 & 40 & 80 \\
\hline
\end{tabular}

図 4 成績入力画面

Fig. 4. Score input screen.

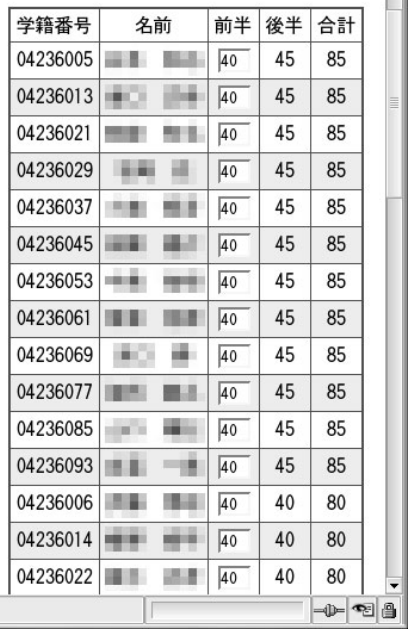

宙

(n)




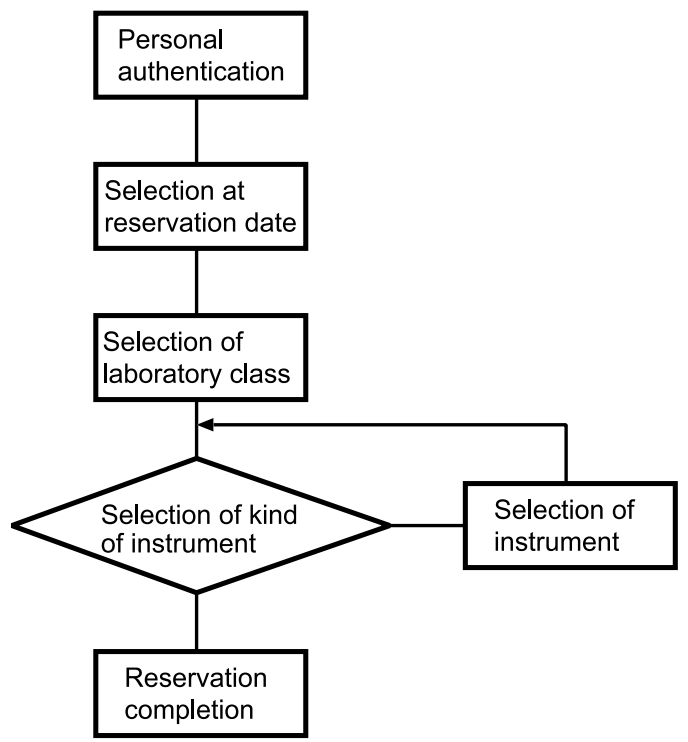

図 6 実験器具の予約の流れ図

Fig. 6. Flowchart of reservation of laboratory instruments.

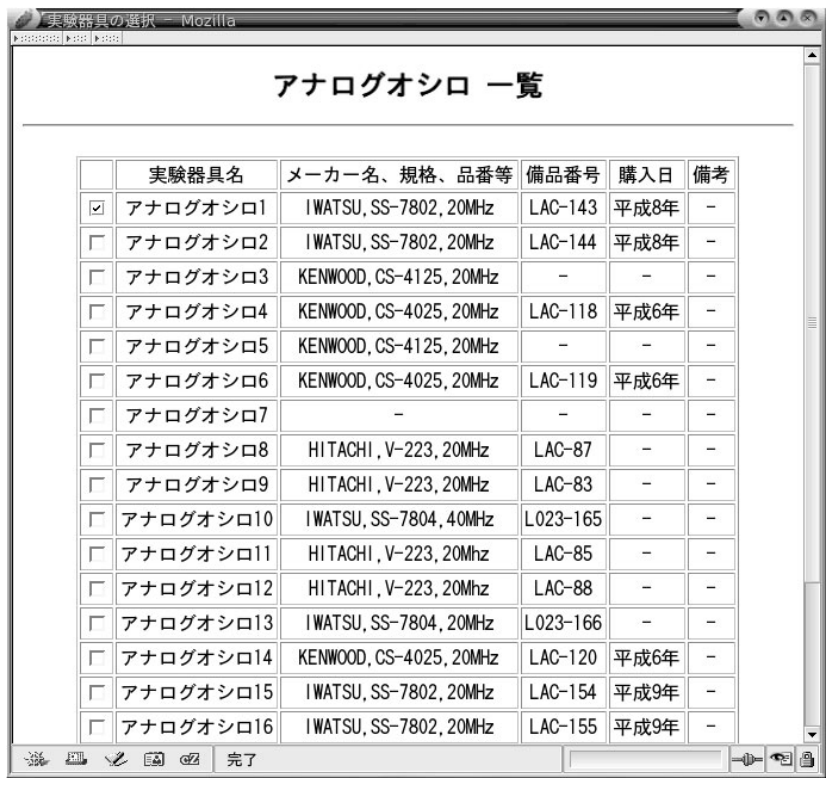

図 7 実験器具の予約画面

Fig. 7. Reservation window of laboratory instruments.

を扱うため，個人認証を行い教員がデータを取り扱うよう にしている。また受講者も本システムを利用することがで きるが，受講者は利用に制限があり，出席管理システムに おける出席状況の確認ページで出席状況の確認を行うこと だけができる。

$\langle 2 \cdot 2\rangle$ 実験器具管理システム図 6 は, 本システム を用いた実験器具予約の流れ図である。実験器具の予約を する祭には，利用者である受講者は，希望する日時に実験 を行うために予約を行う。受講者が予約を行う手順は，ま ず，個人認証を行った後，日時を選択し，次に実験を行う 場所を選択し，実験時に使用する実験器具を選択する。

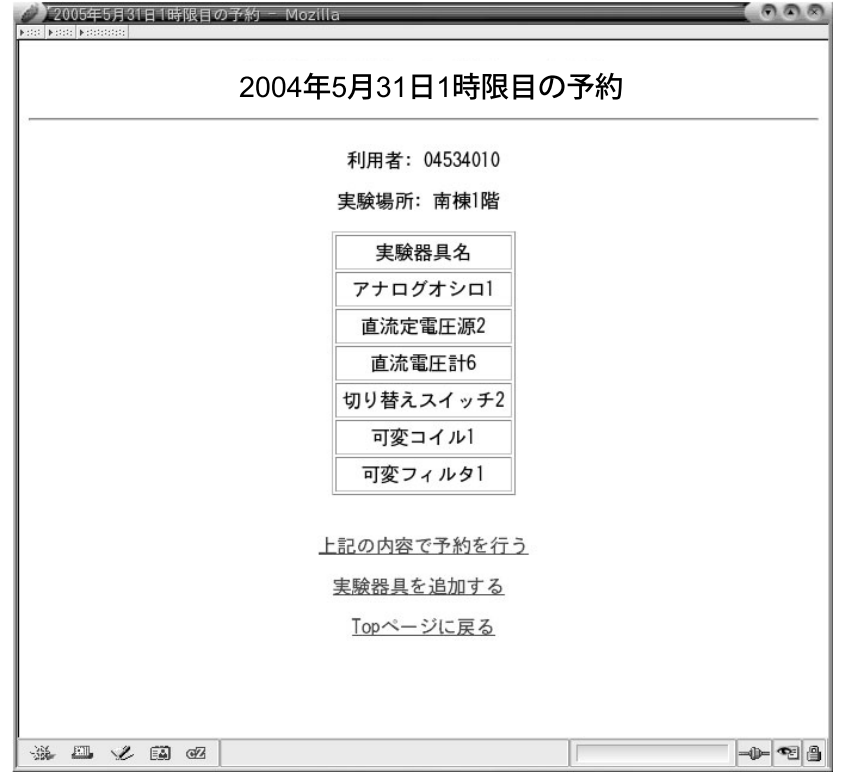

図 8 実験器具の予約確認画面

Fig. 8. Reservation check window of laboratory instruments.

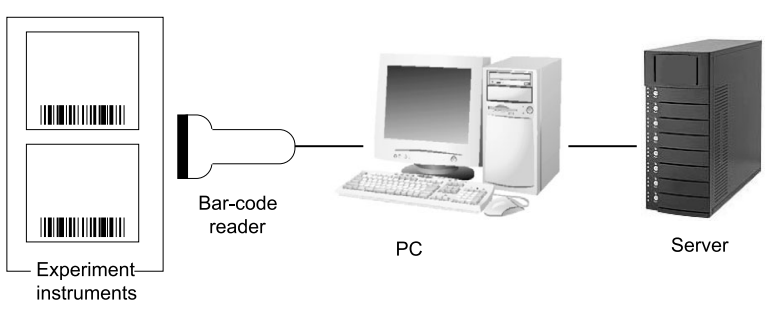

図 9 学生実験器具貸出システムの構成

Fig. 9. System configuration of lending student laboratory instruments.

図 7 は，本システムにおいて受講者が実験器具の予約をす る際の予約画面である。予約可能な実験器具が表示される。

図 8 は, 実験器具の予約確認画面である。日時, 利用者, 学籍番号, 実験室, 実験器具名が表示されている。実験器 具の選択を行うと, この実験器具の確認画面が表示される。 ここで, 予約する実験器具がすべて表示されていなければ, 「実験器具を追加する」を選択して, 使用する実験器具を追 加する。予約する実験器具がすべて表示されていれば，「上 記の内容で予約を行う」を選択すると予約データがデータ ベースに登録され，予約完了となる。

実験器具管理は, 図 9 のようになっている。図 9 のサー バの構成は，図 1 と同様である。本システムは PC に接続 したバーコードリーダを使って，実験器具に貼り付けられ たバーコードを読み取る。実験器具に貼り付けられたバー コードのデータは，サーバ内のデータベースに登録されて いるため, 実験器具のバーコードのデータとサーバ内のデー タベースのデータを照合して実験器具の貸出を行う。

受講者が実験器具を利用する際には，まず，個人認証の 


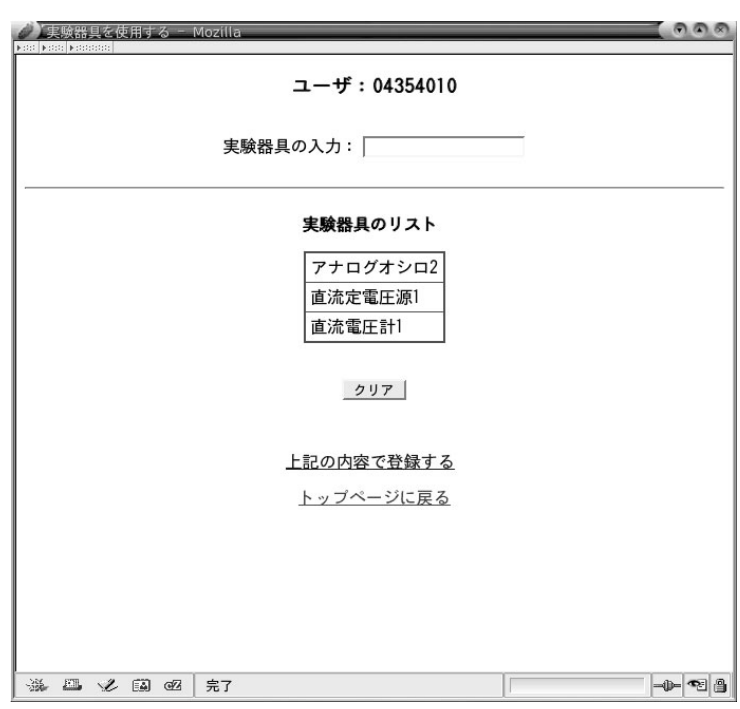

図 10 実験器具の貸出画面

Fig. 10. Lending window of student laboratory instruments.

ため各受講者の学生証に印字されているバーコードで表さ れた学籍番号を使用する。このバーコードにより，受講者 を特定することが可能である。学生証のバーコードをバー コードリーダで読み取り，本システムにログインする。

ログイン後, 図 10 に示す実験器具の貸出画面において, 実験器具に貼り付けられているバーコードを順次，バーコー ドリーダで読み取ることで貸出リストに追加する。すべて の実験器具の選択を終了し, 登録ボタンをクリックすると, データベースに実験器具の貸出データが登録され, 実験器 具の貸出が終了する。

返却時は，実験器具返却画面に打いて貸出時と同様に，実 験器具に貼り付けられているバーコードを順次，バーコー ドリーダで読み取ることで返却する。返却の際は，貸し出 された実験器具があらかじめ貸出リストに表示されており， バーコードを読み取る毎に貸出リストから実験器具を消去 する。ここで，バーコードを一つ読み取る毎に，データベー スに登録されている貸し出した実験器具のデータの返却の 処理を行うため, 貸出リストから実験器具がなくなれば返 却が終了となる。

〈2・3〉予習支援システム予習支援システムでは，受 講者が本システムにログインすると図 11 のような問題ペー ジが表示される。

問題ページは数ページ用意されており，受講者は問題の 答えを選択肢の中から選択して, 次へというボタンをク リックするとその問題は終了となり, 次の問題ページに進 む。ここで，問題に対する解答の選択肢は，Javaの random 関数を用いて選択肢の順番を常にランダムに並び替えて表 示するようにしている。これにより，受講者が正解だけを 覚えて問題に臨むことを防ぎ, 受講者が真剣に問題に取り 組むと考えられる。また，受講者の答えのデー夕はセッショ ン管理を行って抢り，30 分でセッションデータがなくなる

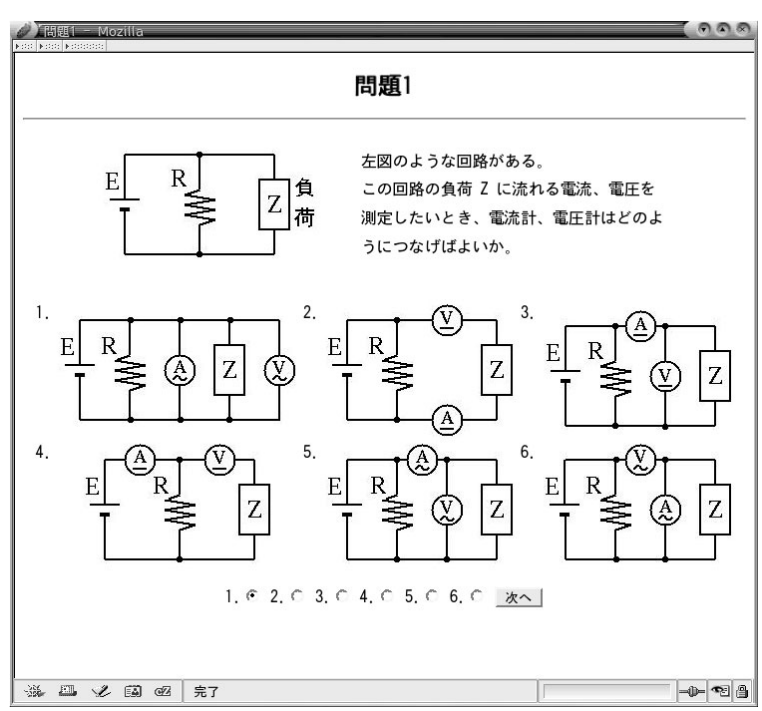

図 11 問題画面

Fig. 11. Question window.

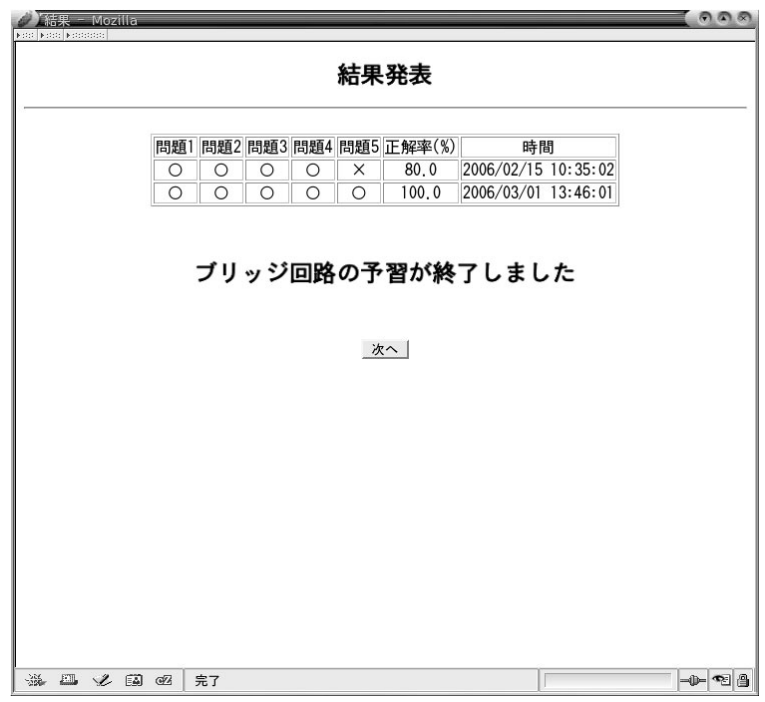

図 12 予習終了画面

Fig. 12. Finish window of preparation.

ため，受講者は 1 問につき 30 分以内に解答して次の問題 に進まなければならない。

問題をすべて解き終えると, 図 12 に示すような結果が 表示される。この結果表示ページでは, 各問題に対する正 誤がそれぞれ表示され，また，問題の正解率も計算されて 表示される。すべての問題に正解すると予習が終了となり, 一つでも不正解があると不合格となる。不合格であれば再 度, 問題を解かなければならないが, 不正解の問題に対し て復習できるように参考文献の提示を行う。これは，何度 も適当に問題を解いて予習を終了寸るのではなく, 不正解 であった問題に対して，学生自身が自主的に勉強し理解し た上で, 再度本システムで予習を行い, 実験の予習に対す る理解を深めるためである。

また，この結果表示ぺージでは，これまでの予習の履歴 
も表示され, 図 12 のように上から第 1 回目, 第 2 回目と いう順に，それぞれの問題に対する結果，正解率，予習を 行った際の日時が表示される。

すべての問題に正解すると，予習の合格ページが表示さ れる。予習の合格ページは予習終了証となっており, 受講 者はこのページを印刷して実験時に担当の教員に提出する。 これにより予習終了の認定がされる。

\section{3. 本システムによって期待される効果}

本システムは，まだ，本格的に当学科の学生実験に導入 されていないので，期待される効果について述べる。

本システムの開発・導入によって, 出席・成績管理シス テムでは，データの一元管理ができるようになり，学生実 験に関わる教務事務に関して, 教員の負担が軽減されると 考えられる。

実験器具管理システムにおいて, 実験器具の予約や貸出 などの一元管理を行うことができるようになる。

また，予習支援システムにおいては，これまで各受講者 が個別に予習を行っていたので, 実験の最低限の準備がで きていない学生もいた。本システムで問題を提供すること により，実験を行うために必要な事前の知識を得ることが でき，受講者が積極的に実験を行うようになり，学生実験 の時間効率が良くなると考えられる。

\section{4. むすび}

本稿で述べた学生実験支援システムでは, 出席・成績管 理システム, 実験器具管理システム, 予習支援システムの 設計・実装を行った。

まず，出席・成績管理システムにおいて，出席管理シス テムでは, 出席データの入力, 変更, 入力された出席デー 夕の一覧表示をWeb 上で行うことが可能である。また，本 システムによって, 出席データの一元管理を行うことも可 能である。

成績管理システムも出席管理システムと同様に成績デー 夕の入力, 変更, 入力された成績データの一覧および平均 点，分散，標準偏差の閲覧をWeb 上で行うことができる。 本システムにより，成績データの一元管理が可能となった。

次に, 実験器具管理システムにおいて，実験器具の予約 では，受講者が希望する日時に実験が行えるように，実験 器具の予約を行うことが可能である。また，実験器具の貸 出では，バーコードリーダを用いて実験器具の管理ができ るようになった。

予習支援システムは，受講者側が Web 上で出題される問 題を解くことで，予習を行うことが可能である。また，予 習の結果の表示や不正解だった問題に対する参考文献の提 示により予習の効果が向上すると考えられる。

今後の課題としては, 実験器具管理システムでは, 現在, バーコードリーダを使用して実験器具の管理を行うシステ ムとなっているが，より利便性を図るために RFID (Radio Frequency Identification) ${ }^{(10)}$ タグの導入が挙げられる。ま
た, 予習支援システムでは, 出題形式をさらに工夫するこ とで，予習がより充実すると考えられる。

謝 辞

本研究を遂行するにあたり，2005 年 3 月に佐賀大学大学 院工学系研究科博士前期課程電気電子工学専攻を修了した (現：アイコム株式会社勤務) 赤木圭太氏に多大な協力を頂 いた。ここに，謝意を表する。

(平成 17 年 8 月 22 日受付, 平成 18 年 5 月 2 日再受付)

\section{文献}

(1) T. Miyabara, M. Takahashi, and K. Tanaka: "Web based Remote Laboratory for supporting students laboratory work", The Paper of Technical Report of IEICE, No.ET2003-107, pp.53-58 (2004-3) (in Japanese)

宮原＼cjkstart剛·高橋光生・田中清臣:「学生実験支援のためのインターネット を利用した遠隔実験環境」, 信学技報, No.ET2003-107, pp.53-58 (2004-3)

(2) http://www.jabee.org/

(3) K. Furukawa, M. Ohchi, and T. Furukawa: "Development of Self Study Support System for Electric Circuits aided by Measured Waveforms using Java Applet Oscilloscope", SICE Kyusyu Branch Annual Conference, No.203C4, pp.295-296 (2004-12) (in Japanese)

古川健司・相知政司・古川達也 :「Java アプレットオシロスコープ による実波形表示可能な電気回路学習支援システムの開発」, 第 23 回計測自動制御学会九州支部学術講演会, No.203C4, pp.283-284 (2004-12)

(4) T. Furukawa, M. Ohchi, and K. Kurakaki: "Design and Implementation of Streaming Video and Measurement Data Distribution System over the Internet", IEEJ Trans. EIS, Vol.125, No.7, pp.1077-1083 (2005-7) (in Japanese) 古川達也・相知政司・倉坦健治:「インターネットを援用した遠隔操 作可能な動画・計測デー夕配信システムの構築」, 電学論 C, 125, 7, pp.1077-1083 (2005-7)

(5) H. Tanaka, T. Furukawa, and M. Ohchi: "Development of Course Registration Support Database System based on Load Sharing System using PostgreSQL and PGCluster with Bidirectional Replication", SICE Kyusyu Branch Annual Conference, No.203B5, pp.283-284 (2004-12) (in Japanese) 田中宽崇・古川達也・相知政司 : 「PostgreSQL と双方向レプリケー ションシステム PGCluster による負荷分散を実現する大学履修登 録支援データベース・システムの開発」, 第 23 回計測自動制御学会 九州支部学術講演会, No.203B5, pp.283-284 (2004-12)

(6) http://www.apache.org/

(7) http://www.postgresql.org/

(8) http://jakarta.apache.org/tomcat/

(9) http://www.openssl.org/

（10）加瀬一朗：RFID の現状と今後の動向，電気通信協会 (2005)

相 知 政 司 (正員) 1964 年 12 月 8 日生。1989 年 3 月長崎

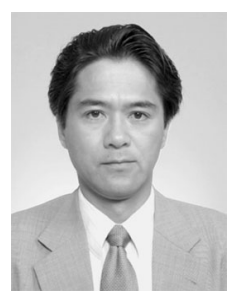
大学大学院工学研究科修士課程修了。同年 4 月 NTT に入社。1 1991 年 4 月佐賀大学理工学部助 手。1993 年 4 月同電子工学科助手へ配置替。 2000 年 4 月同電気電子工学科講師, 2002 年 1 月同助 教授。 2005 年 3 月から 2005 年 12 月まで米国ワ シントン州立大学客員研究員, 現在に至る。電気 電子計測並びにインターネットを援用した教育工 学に関する研究に従事。博士 (工学)。計測自動制御学会, 電子情報通 信学会, 日本シミュレーション学会, 日本 AEM 学会, 日本ロボット 学会会員。 
青 木 規 至 （学生員） 1981 年 5 月 20 日生。 2004 年 3 月佐 賀大学理工学部電気電子工学科卒業。同年 4 月同 大学大学院工学系研究科博士前期課程電気電子工 学専攻入学。 2006 年 3 月同専攻修了。同年 4 月 同大学大学院工学系研究科博士後期課程システム 生産科学専攻進学。電磁界の計測並びに Web と データベースを応用したシステムに関する研究に 従事。計測自動制御学会学生員, 日本音響学会学
川 原 俊 宏 (非会員) 1982 年 3 月 7 日生。 2004 年 3 月佐賀

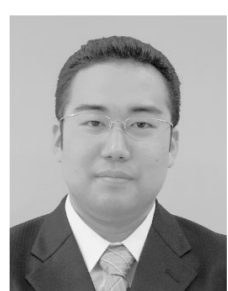
大学理工学部電気電子工学科卒業。同年 4 月同大 学大学院工学系研究科博士前期課程電気電子工学 専攻入学。 2006 年 3 月同専攻修了。同年 4 月安川 情報システム (株) 入社。在学中は, PostgreSQL を援用した Web ベースの学生実験支援システム の開発に従事。

生員。

古 川達 也 (正員) 1956 年 6 月 21 日生。1984 年 3 月九 州大学大学院工学研究科博士後期課程単位取得退 学。同年 4 月長崎大学工学部助手。1986 年佐賀 大学理工学部電気工学科講師, 1987 年同助教授。 1993 年 4 月同電子工学科助教授へ配置替。 2001 年 4 月電気電子工学科教授, 現在に至る。数值解 析, 計算機応用工学に関する研究に従事。工学博 士。計測自動制御学会, 日本シミュレーション学 会, 日本 AEM 学会, 電子情報通信学会, 情報処理学会会員。 